\title{
Экситоны и трионы в оптическом отклике двумерных кристаллов
}

\author{
М.М. Глазов \\ Физико-технический институт им. А.Ф.Иоффе, Санкт-Петербург, 194021, Политехническая, 26
} эл.nочта: glazov@coherent.ioffe.ru

DOI $10.34077 /$ RCSP2021-21

Последнее десятилетие отмечено появлением новых полупроводниковых наносистем с экстремальными свойствами - атомарно-тонких полупроводников. Яркими представителями этого класса материалов являются моноатомные слои графена и мономолекулярные слои дихалькогенидов переходных металлов, например, $\mathrm{MoS}_{2}$. В отличие от графена в монослоях дихалькогенидов переходных металлов в точках K и K' на границах зоны Бриллюэна реализуется прямая запрещенная зона $\sim 2$ эВ, что делает эти нанообъекты особенно перспективными с точки зрения фотоники.

Оптические свойства таких систем контролируются главным образом экситонами - электрондырочными парами, связанными кулоновским взаимодействием. Особенности зонной структуры и экранировки кулоновского взаимодействия в таких системах приводят к значительным энергиям связи экситонов и необычной серии возбужденных экситонных состояний $[1,2]$.

В данном докладе приводится обзор основных экситонных эффектов в атомарно-тонких кристаллах на основе дихалькогенидов переходных металлов. Особое внимание уделено новым эффектам, присущим именно этим экстремально-двумерным системам, включая управление радиационным временем жизни экситона и временем его спиновой релаксации за счет изменения окружения монослоя $[3,4]$, формирование трионов - трехчастичных комплексов - за счет взаимодействия экситонов с резидентными носителями заряда [5], фононные каскады с участием экситонов [6], а также проявления межслоевых экситонов в нелинейном оптическом отклике таких систем [7]. Теоретические модели эффектов сопоставляются с данными экспериментов.

Работа поддержана грантом РНФ № 19-12-00051.

\section{Лumepamypa}

[1] G. Wang, A. Chernikov, M. M. Glazov, et al. // Rev. Mod. Phys. 2018 V. 90 P. 021001.

[2] М.В. Дурнев, М.М. Глазов // УФН 2018 Т. 188 С. 913.

[3] H.H. Fang, B. Han, C. Robert, M.A. Semina, et al. // Phys. Rev. Lett. 2019 V. 123 P. 067401.

[4] A. I. Prazdnichnykh, M. M. Glazov, et al. // Phys. Rev. B 2021 V. 103 P. 085302.

[5] K. Wagner, E. Wietek, J. D. Ziegler, M. A. Semina, et al. // Phys. Rev. Lett. 2020 V. 125, P. 267401.

[6] I. Paradisanos, G. Wang, E. M. Alexeev, et al. // Nat. Comm. 2021 V. 12 P. 538.

[7] S. Shree, D. Lagarde, L. Lombez, et al. // Preprint arXiv 20212104.01225. 